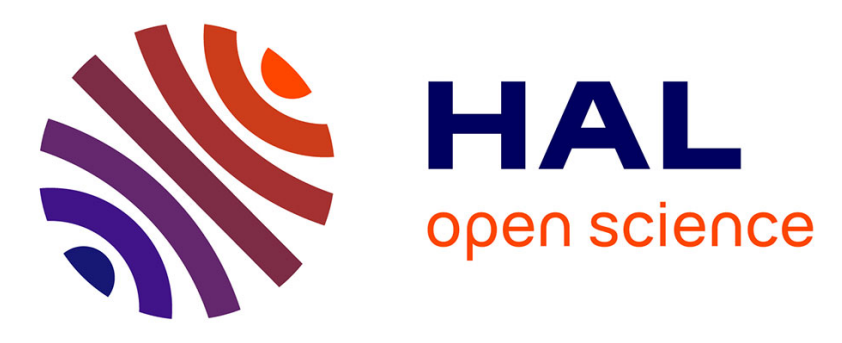

\title{
Influence of different parameters in the fire behaviour of seven hardwood species
}

\author{
Laia Haurie, María Pilar Giraldo, Ana María Lacasta, Joaquín Montón, \\ Rodolphe Sonnier
}

\section{- To cite this version: \\ Laia Haurie, María Pilar Giraldo, Ana María Lacasta, Joaquín Montón, Rodolphe Sonnier. Influence of different parameters in the fire behaviour of seven hardwood species. Fire Safety Journal, 2019, 107, pp.193-201. 10.1016/j.firesaf.2018.08.002 . hal-02428274}

\section{HAL Id: hal-02428274 https://hal.mines-ales.fr/hal-02428274}

Submitted on 3 Jun 2021

HAL is a multi-disciplinary open access archive for the deposit and dissemination of scientific research documents, whether they are published or not. The documents may come from teaching and research institutions in France or abroad, or from public or private research centers.
L'archive ouverte pluridisciplinaire HAL, est destinée au dépôt et à la diffusion de documents scientifiques de niveau recherche, publiés ou non, émanant des établissements d'enseignement et de recherche français ou étrangers, des laboratoires publics ou privés. 


\title{
Influence of different parameters in the fire behaviour of seven hardwood species
}

\author{
Laia Haurie $^{\mathrm{a}}$, María Pilar Giraldo ${ }^{\mathrm{b}, *}$, Ana María Lacasta ${ }^{\mathrm{a}}$, Joaquín Montón ${ }^{\mathrm{a}}$, Rodolphe Sonnier \\ ${ }^{a}$ Universitat Politècnica de Catalunya UPC, Av. Dr. Marañón, 44-50, 08028, Barcelona, Spain \\ ${ }^{\mathrm{b}}$ Forest Science and Technology Centre of Catalonia CTFC, Catalan Institute of Wood INCAFUST, Ctra. Sant Llorenc, Km 2, 25280, Solsona, Spain

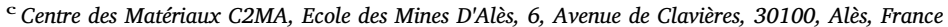

\begin{abstract}
A B S T R A C T
Wood is a widely used material in the construction sector, both in structural and non-structural applications. Tropical species are appreciated for their high quality and durability in furniture, outdoor and indoor claddings and floors. However, limited information exists about fire reaction of tropical wood. Density is one of the factors that influence the rate of pyrolysis reactions and consequently the charring rate. However, other wood characteristics such as the mineral content also exert an influence on the pyrolysis combustion of wood. Hardwoods present a complex morphological structure and a significant amount of minerals, extracts and exudates. In this work, we study the fire reaction of seven species of tropical hardwood using various fire tests. Results are compared from one test to other one and are discussed in relation with physicochemical properties of wood species. The results show that although there is some correlation between high density and ignition time, parameters such as morphology and mineral content are also relevant.
\end{abstract}

Keywords:

Fire behaviour

Hardwood

Pyrolysis

Flammability

Thermal stability

\section{Introduction}

The use of wood in buildings, not only in structural applications, is object of increasing interest. In the market, it is possible to find a huge variety of wood species. The use of tropical wood species is increasing in some European countries for the high qualities they can offer, especially for structural and separating elements, interior claddings, flooring and furniture. Several articles treat the fire resistance and charring rate of tropical woods [1,2], but limited literature can be found about the fire reaction of this kind of wood. In applications such as cladding or furniture fire reaction is an important aspect to evaluate the contribution of wood in case of fire.

Generally, wood density is considered one of the most important factors for achieving a better fire behaviour due to its influence on the rate of pyrolysis reactions and consequently on the charring rate [3]. When a wooden piece is exposed to fire, it undergoes thermal degradation, including different and complex thermo-physical and thermo-chemical processes such as heat transfer, drying, pyrolysis, charring, mass loss and smouldering. The morphology and the chemical components of the wood species strongly affect all these processes [4].

Wood is a natural composite with a set of specialized cells that perform important functions as providing mechanical strength to the branches, conducting essential liquids and storage of nutrients reserves.
Cellulose, hemicellulose, lignin, extractives and exudates are the main components of wood. Cellulose is a polymer conformed by a high number of glucose units. The degree of polymerization (DP) varies depending on the wood species, but cellulose from hardwoods has usually a DP above 3000 [5]. Hemicellulose is formed by low molecular weight polysaccharides with a DP of around 200 [6] and lignin, the third polymeric constituent of wood, is a cross-linked aromatic polymer [7]. These differences in the molecular composition explain the lower thermal decomposition of hemicellulose, between 180 and $350^{\circ} \mathrm{C}$, followed by cellulose $\left(275-350^{\circ} \mathrm{C}\right)$ and lignin $\left(250-500{ }^{\circ} \mathrm{C}\right)$ [8]. Several authors have described the different stages occurred during combustion of wood $[4,9]$ :

- $100-200^{\circ} \mathrm{C}$ : release of water and non-combustible gases.

- 200 - $300^{\circ} \mathrm{C}$ : pyrolysis of hemicellulose and lignin and production of charred wood.

- 300 - $455^{\circ} \mathrm{C}$ : depolymerisation of cellulose and lignin and release of flammable gases.

- $450^{\circ} \mathrm{C}$ : oxidation and smouldering of the charred wood residue.

Extractives and exudates exert a significant influence on essential characteristics of trees such as the variety of colour, smell, density, dimensional stability, durability and resistance to attack by fungi and

\footnotetext{
* Corresponding author.

E-mail address: pilar.giraldo@incafust.cat (M.P. Giraldo).
} 
insects [10]. These compounds can also affect the calorific value and, therefore the flammability [11]. Trees also contain different minerals, which make a fundamental contribution in their metabolism. Most minerals are absorbed from soil through its root system, while others are absorbed from air through the leaves. Some of the metallic elements found in the mineral salts are: $\mathrm{Al}, \mathrm{Ca}, \mathrm{Fe}, \mathrm{K}, \mathrm{Mg}, \mathrm{Na}, \mathrm{Mn}$ and Ni. These elements are combined to form oxides, carbonates, silicates, chlorides, phosphates, nitrates or sulphates. These minerals can play a significant role in the pyrolysis process of wood through a catalytic effect that influences the temperatures of pyrolysis and the products released $[12,13]$. Total inorganics in wood can be evaluated by determination of ash content after combustion of the material. Zule et al. indicate that woods typically contain from 0.1 to $1.5 \%$ of ash, but these contents may be higher in some tropical species [14]. Torelli et al. studied $43 \mathrm{Mex}-$ ican tropical hardwoods and they found amounts of silica up to $4.7 \%$ for one of the species [15]. In the case of Avila-Calderon et al. the evaluation of the ash content on 3 Mexican woods revealed ash contents of $6.2 \%$ for one of the studied species [16]. These results indicate that tropical woods are especially rich in different inorganic constituents.

This work provides a detailed study of the fire reaction of seven species of tropical hardwood using various fire tests including cone calorimeter. The species selected have a wide range of densities, as well as diverse physical and chemical characteristics. This allows us to carry out a complete study to observe the influence of different parameters on the fire behaviour and provide new data about these species. Therefore, this study can be useful to increase the knowledge about the factors affecting the fire performance of tropical hardwoods.

\section{Materials and methods}

\subsection{Materials}

Seven species of tropical hardwoods from Mexico have been included in this study. Table 1 summarizes the seven hardwoods species studied in this research. Even though all the samples are hardwoods, there exist remarkable differences in their densities as well as in their colour and surficial aspect.

Wood samples were conditioned at $21^{\circ} \mathrm{C}$ and a relative humidity of $55 \%$ prior to their characterization. The equilibrium moisture content of the samples was measured by the oven dry method and is shown in Table 1. As it can be observed the values are quite similar being the denser wood species the ones with less moisture content.

\subsection{Characterization methods}

In order to evaluate the thermal and fire behaviour of the wood samples the tests described below were performed. Scanning electron microscopy was used to evaluate the morphology of the different wood species as well as the presence of mineral elements.

\subsubsection{Thermogravimetric analysis}

Thermogravimetric analyses (TGA) were performed using a furnace coupled with a precision scale. This device allowed testing larger samples, between 0.3 and $1.5 \mathrm{~g}$, than the conventional

Table 1

Characteristics of different wood species.

\begin{tabular}{llll}
\hline Code & Scientific name & Density $\mathrm{kg} / \mathrm{m}^{3}$ & Moisture (\%) \\
\hline TD & Tabebuia donnell-smithii & 448 & 8.9 \\
EC & Enterolobium cyclocarpum & 504 & 8.9 \\
TR & Tabebuia rosea & 604 & 9.0 \\
SH & Swietenia humilis & 655 & 9.9 \\
LA & Lysiloma acapulcensis & 685 & 9.2 \\
CA & Cordia elaeagnoides & 1130 & 7.3 \\
TC & Tabebuia chrysantha & 1234 & 8.3 \\
\end{tabular}

thermogravimetric equipment, which is interesting for heterogeneous samples. The samples were heated at $4{ }^{\circ} \mathrm{C} / \mathrm{min}$ until $1000^{\circ} \mathrm{C}$ under air atmosphere. One TGA was performed for each wood species.

\subsubsection{Limiting oxygen of index (LOI)}

The Limiting Oxygen Index (LOI) was determined following the standard UNE-EN ISO 4589. Although LOI test primarily was developed for plastics, this method has been successfully used to determine fire performance of wood [17]. The standard establishes the test procedure to determine the LOI on vertically oriented small specimens, in this case of $70 \mathrm{~mm} \times 10 \mathrm{~mm} \times 1 \mathrm{~mm}$, under a mixture of nitrogen and oxygen flow. LOI is the minimum concentration of oxygen at which a specimen will support combustion under the criteria defined in the standard.

\subsubsection{Epiradiator test}

A radiator device described in the Spanish UNE 23725-90 standard was employed to evaluate the time to ignition and the ability to extinguish the flame after the heating source was removed from the sample. Specimens $(70 \times 70 \times 10 \mathrm{~mm})$ were placed on a metallic grid $3 \mathrm{~cm}$ below a heat source of $500 \mathrm{~W}$, which was taken away and put back after each ignition and extinction. Under this test conditions the heat flux on the surface of the sample is $30 \mathrm{~kW} / \mathrm{m}^{2}$. Three specimens of each wood species were tested, and the parameters determined were the number of ignitions (No), the time at which the first ignition occurs $\left(\mathrm{t}_{0}\right)$ and the average time of flame persistence during the first $5 \mathrm{~min}$ of combustion $\left(\mathrm{t}_{\mathrm{m}}\right)$.

\subsubsection{Pyrolysis combustion flow calorimeter (PCFC)}

A pyrolysis combustion flow calorimeter from Fire Testing Technology was used to measure the heat release rate as a function of the temperature of the different wood samples. The equipment consists of a pyrolysis chamber where the samples were heated under nitrogen atmosphere up to $750{ }^{\circ} \mathrm{C}$ at $1{ }^{\circ} \mathrm{C} / \mathrm{s}$. The evolved gases were then transported by an inert gas to the combustor that works at $900{ }^{\circ} \mathrm{C}$ in a flow of oxygen $\left(20 \mathrm{~cm}^{3}\right)$ and nitrogen $\left(80 \mathrm{~cm}^{3}\right)$.

\subsubsection{Cone calorimeter}

The cone calorimeter tests were carried out following the procedures indicated in the ISO 5660 standard with a FTT cone calorimeter. The testing procedure was adapted to test square specimens of $70 \times 70 \times 10 \mathrm{~mm}^{3}$ witha heat flux of $35 \mathrm{~kW} / \mathrm{m}^{2}$. Each species was tested twice. Good reproducibility was obtained.

\subsubsection{Scanning electron microscopy (SEM)}

The morphology of the samples was studied by scanning electron microscopy using an Environmental microscope, ESEM Quanta 200 FEI. Elemental analysis using energy dispersive X-ray spectroscopy (EDS) was also performed to identify the elements present in the mineral crystals observed inside the wood cells.

In order to obtain more information about the amount and nature of the inorganic phases, the different wood samples were calcined at $800{ }^{\circ} \mathrm{C}$ during $1 \mathrm{~h}$ to obtain the residue. This residue was also observed and analyzed by SEM and EDS respectively.

\section{Results and discussions}

Since the density of the wood species ranges from 448 to $1234 \mathrm{~kg} /$ $\mathrm{m}^{3}$, it is expected that this parameter will influence greatly the fire behaviour. Nevertheless, the internal structure differs significantly from one wood species to the other one. The morphology of the different wood samples was examined with SEM (Fig. 1). It was observed that LA, CA and TC have a more compact morphology compared with the other samples. This is not surprising in woods species with high density as CA and TC; however, it is remarkable in a medium density wood as LA. Tangential section of LA shows mostly uniseriate and biseriate rays and seldom triseriate rays. Many cells in uniseriate rays are saturated 


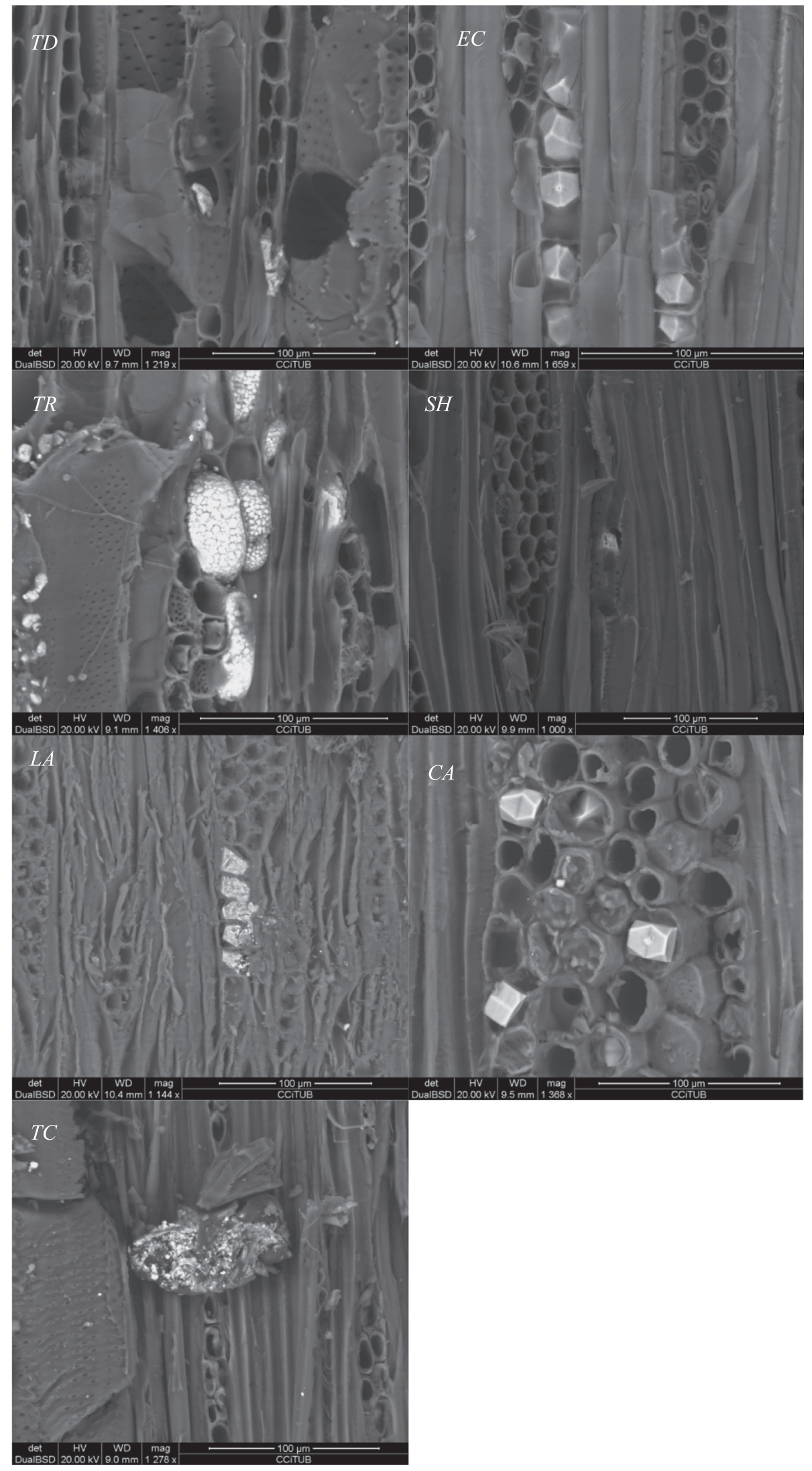

Fig. 1. SEM morphology of wood samples. 

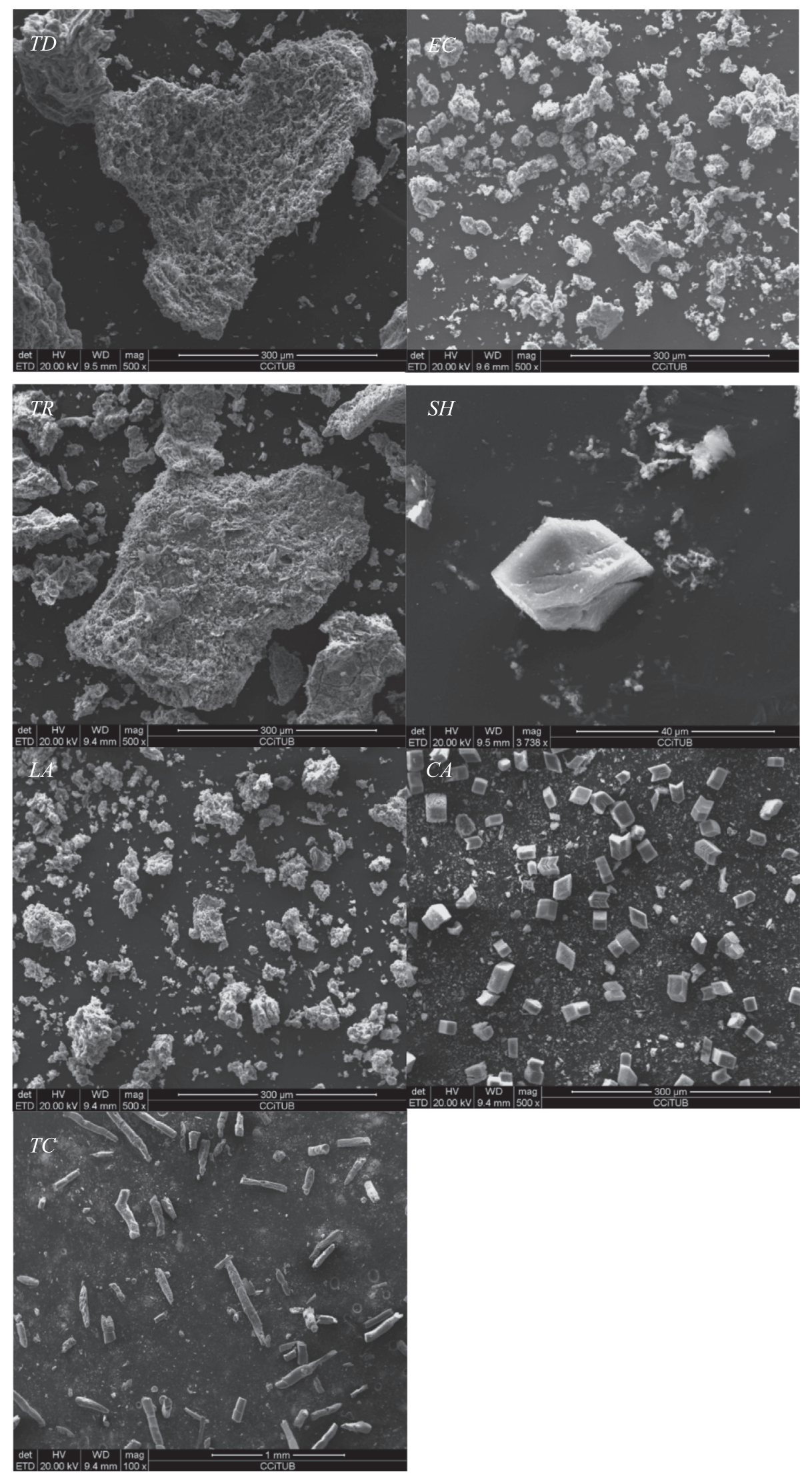

Fig. 2. SEM images from the calcined residues. 
Table 2

Summary of results of calcined residue analysis.

\begin{tabular}{lll}
\hline Code & Calcined Residue (\%) & Main elements \\
\hline TD & 0.6 & $\mathrm{P}, \mathrm{Ca}, \mathrm{K}$ \\
EC & 0.5 & $\mathrm{Ca}, \mathrm{K}$ \\
TR & 0.5 & $\mathrm{Ca}$ \\
SH & 0.4 & $\mathrm{Ca}$ \\
LA & 1.3 & $\mathrm{~K}, \mathrm{~S}, \mathrm{Ca}$ \\
CA & 1.5 & $\mathrm{Ca}$ \\
TC & 2.8 & $\mathrm{Ca}$ \\
\hline
\end{tabular}

with minerals and also some saturated tracheids can be found. This saturation may influence the oxygen and gases flow during the combustion.

Wood samples were calcined in order to concentrate and analyse the minerals present in each wood species (Fig. 2). Table 2 shows the amount of solid residue and the nature of main elements contained in each sample after calcination and detected by EDS. From the crystal habit it can be deduced that samples EC, SH, CA contain whewellite, a monohydrated calcium oxalate. This is in good agreement with the formation of calcium oxide in the calcination of the wood, which is subsequently transformed to calcium hydroxide or calcium carbonate. In sample LA, the presence of two types of inorganic compounds was also observed. One of the substances was rich in sulphur and potassium, probably a form of potassium sulphate, and the other one contained calcium as the main element. Several authors reported the influence of the inorganic compounds in the modification of the thermal decomposition and pyrolysis of lignocellulosic products. T. Hosoya et al. mentioned the influence of inorganic substances on the higher production of glycoaldehyde, hydroxyacetone and carbonized products during the wood pyrolysis [18]. K. Raveendran et al. found that the amount of potassium or zinc together with the lignin content modify the pyrolysis of biomass [19]. In general, inorganic matter is believed to increase char formation and inhibit the formation of volatile products [20]. On the other hand, S. Liodakis et al. did not detect a significant influence of the inorganic phases on the ignitability of wood [21].

The thermogravimetric curves of the different wood samples are shown in Fig. 3. The first weight loss step $\left(<150^{\circ} \mathrm{C}\right)$ is assigned to the release of water. The degradation after $250^{\circ} \mathrm{C}$ occurs in several steps for all species. In this range of temperatures $\left(250-400{ }^{\circ} \mathrm{C}\right)$, there is a significant relation between the thermal stability and the density. The less dense species, TD, decomposes at significantly lower temperatures than the rest of the wood samples. This is probably due to the presence of high levels of hemicellulose and reduced contents of cellulose and lignin. EC, TR, LA and SH decompose in a similar way. Denser wood samples, such as CA and TC, exhibit the highest thermal stability. Moreover at $450{ }^{\circ} \mathrm{C}$, weight loss is only $60 \mathrm{wt} \%$ for these two woods versus $90-100 \mathrm{wt} \%$ for all other species. The elevated contents of lignin are probably responsible of this behaviour. Decomposition continues up to $600{ }^{\circ} \mathrm{C}$. A comparison between the thermogravimetric curves at high temperature for TD and CA or TC shows a shift of almost $150-200^{\circ} \mathrm{C}$ between them.

Pyrolysis in PCFC is carried out under nitrogen. Moreover, the sample size is very low and does not influence the heat release rate curves (no thermal inertia). Therefore, no effect of the density is expected. Fig. 4 shows the curves for all wood species. Table 3 lists the main data. The peak of heat release rate appears in a narrow temperature range from 346 to $373{ }^{\circ} \mathrm{C}$ and its intensity ranges from 80 to $130 \mathrm{~W} / \mathrm{g}$. Dorez et al. have obtained similar values for a set of lignocellulosic materials [22], including cellulose, hemicellulose, lignin and natural fibres. Nevertheless, total heat release is slightly higher for wood species (8.2-13.3 kJ/g versus $5.1-9.1 \mathrm{~kJ} / \mathrm{g}$ in Dorez work). Note that LA is characterized by the lowest pHRR $(80 \mathrm{~W} / \mathrm{g})$ and THR $(8.2 \mathrm{~kJ} /$ g) but also by a shoulder at low temperature (around $250{ }^{\circ} \mathrm{C}$ ). On the contrary, CA exhibits the highest pHRR (126 W/g) and THR $(13.3 \mathrm{~kJ} /$ g). Obviously, the differences between the wood species are lower than in aerobic pyrolysis (in thermogravimetric experiments).

The main results of epiradiator test and LOI test are summarized in Table 4. The initial ignition time increases with the density of the wood species (Fig. 5). Only CA sample seems to exhibit a slightly lower TTI than expected. LOI values range from 21.1 to 26.5 . It is noteworthy that the three densest species (LA, CA and TC) exhibit the highest values. Nevertheless, the relation between LOI and density is rather rough. In particular LA exhibits the highest LOI. This wood species seems also to be more self-extinguishing than the other ones. The flame persistence is only 9 s versus $16-29$ s for the other species. On the other hand, the TD sample with lowest density obtained the worst results in both epiradiator and LOI tests. However, once again the correlation between the flame persistence and the density as well between LOI and flame persistence appears limited. No relation is observed between the weight loss and the other data, as total burning time (calculated from the number of ignitions and the average flame persistence) or LOI. These

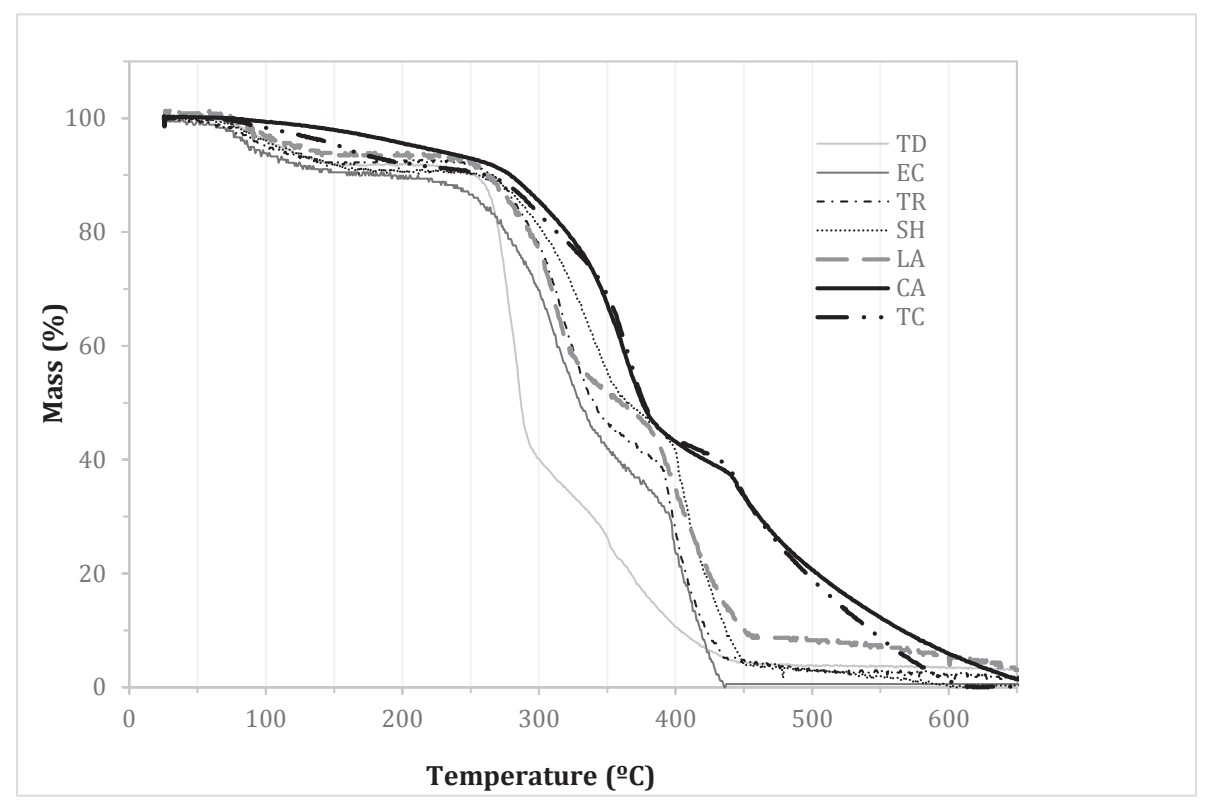

Fig. 3. TGA curves of the seven hardwood species. 


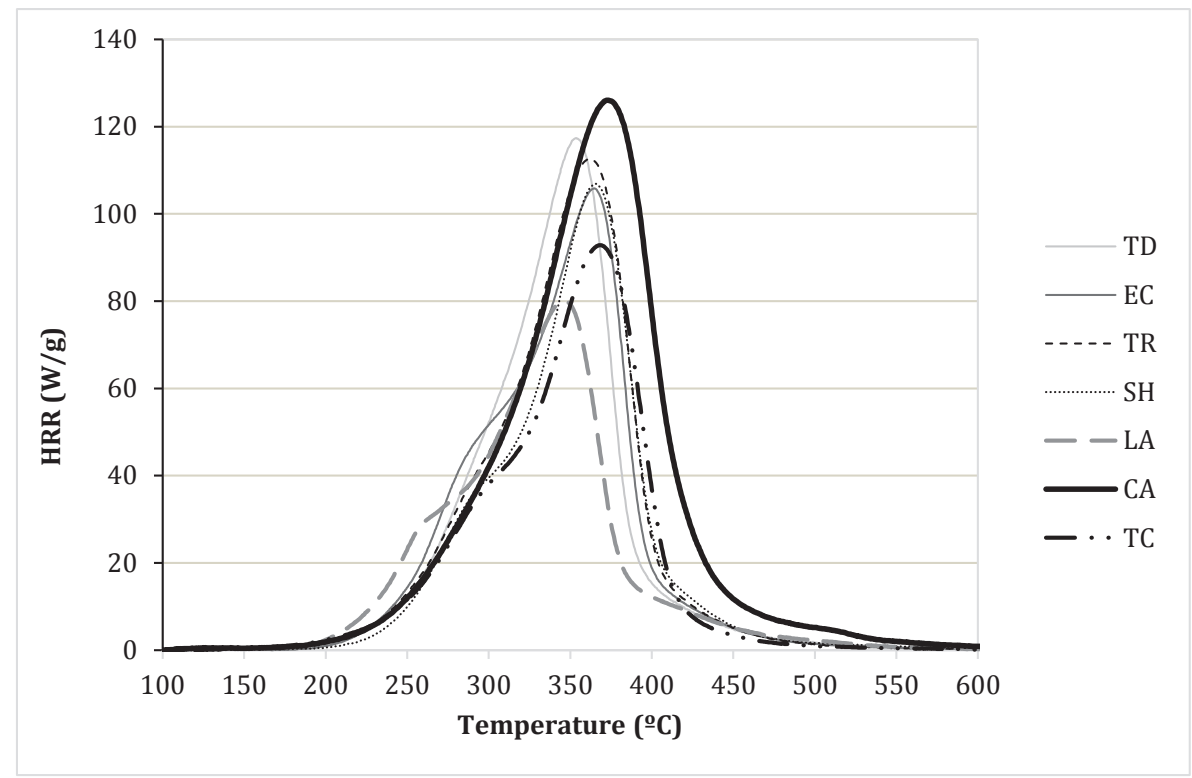

Fig. 4. HRR versus temperature for all wood species in PCFC.

Table 3

Values of pHRR, TpHRR and THR obtained with the PCFC tests.

\begin{tabular}{lllll}
\hline Code & Density $\left(\mathrm{kg} / \mathrm{m}^{3}\right)$ & pHRR $(\mathrm{W} / \mathrm{g})$ & TpHRR $\left({ }^{\circ} \mathrm{C}\right)$ & THR $(\mathrm{kJ} / \mathrm{g})$ \\
\hline TD & 448 & 117 & 354 & 10.1 \\
EC & 504 & 106 & 365 & 10.0 \\
TR & 604 & 113 & 362 & 10.5 \\
SH & 655 & 107 & 366 & 9.5 \\
LA & 685 & 80 & 346 & 8.2 \\
CA & 1130 & 126 & 373 & 13.3 \\
TC & 1234 & 93 & 368 & 9.0 \\
\hline
\end{tabular}

Table 4

Summary of results of flammability and LOI testing.

\begin{tabular}{lllllll}
\hline Code & $\begin{array}{l}\text { Density } \\
\left(\mathrm{kg} / \mathrm{m}^{3}\right)\end{array}$ & $\begin{array}{l}\text { Initial } \\
\text { ignition } \\
(\mathrm{s})\end{array}$ & $\begin{array}{l}\text { Number of } \\
\text { ignitions }\end{array}$ & $\begin{array}{l}\text { Avg. flame } \\
\text { persistence (s) }\end{array}$ & $\begin{array}{l}\text { Weight } \\
\text { loss }(\mathrm{g})\end{array}$ & LOI (\%) \\
\hline TD & 448 & 17 & 8 & 29 & 6.97 & 21.1 \\
EC & 504 & 17 & 12 & 16 & 4.6 & 24 \\
TR & 604 & 24 & 8 & 29 & 3.75 & 21.5 \\
SH & 655 & 28 & 14 & 16 & 4.77 & 23.1 \\
LA & 685 & 31 & 16 & 9 & 3.4 & 26.5 \\
CA & 1130 & 37 & 9 & 26 & 2.28 & 25.1 \\
TC & 1234 & 49 & 13 & 20 & 4.77 & 24 \\
\hline
\end{tabular}

results show that despite wood density has an influence on the fire performance it cannot be taken as the only affecting factor.

Cone calorimeter is a powerful tool to study the flammability of samples. Fig. 6 shows typical curves of CA and EC, respectively high and low-density species. All samples exhibit similar curves with two peaks of heat release rate. The second peak is usually assigned to the breakdown of a char layer or to the change from thick to thin thermal behaviour [23]. When the flame vanishes, heat release rate drops quickly up and stabilizes around $30-80 \mathrm{~kW} / \mathrm{m}^{2}$. This plateau corresponds to thermo-oxidation of the residue.

Main cone calorimeter data are listed in Tables 5 and 6. Sample weight varies from one wood species to the other one. This obviously implies changes in some data as total heat release in $\mathrm{MJ} / \mathrm{m}^{2}$, time to pHRR, time to plateau or flame out. For thermally thin samples, timeto-ignition or pHRR also depend on sample weight. Nevertheless, considering the duration of burning, the samples can be reasonably

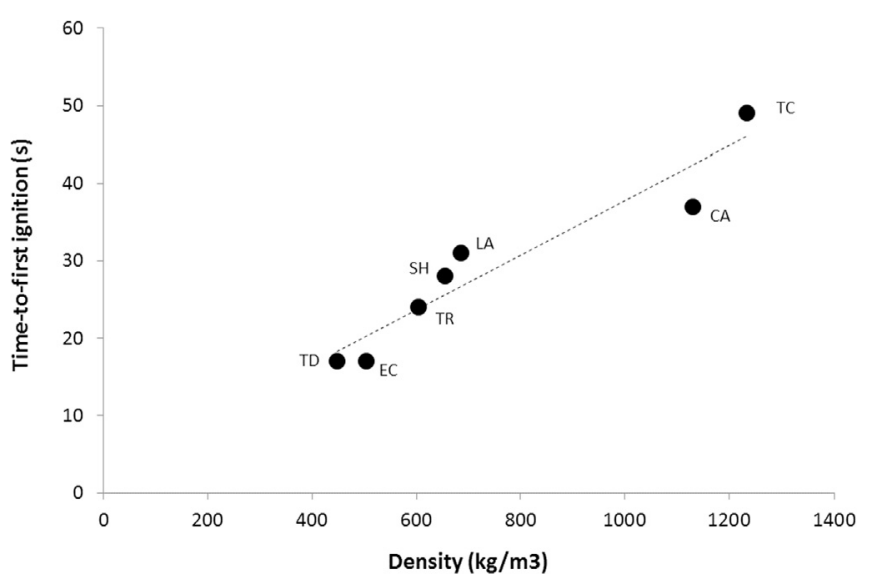

Fig. 5. Time-to-first ignition versus density for all wood species according to epiradiator test.

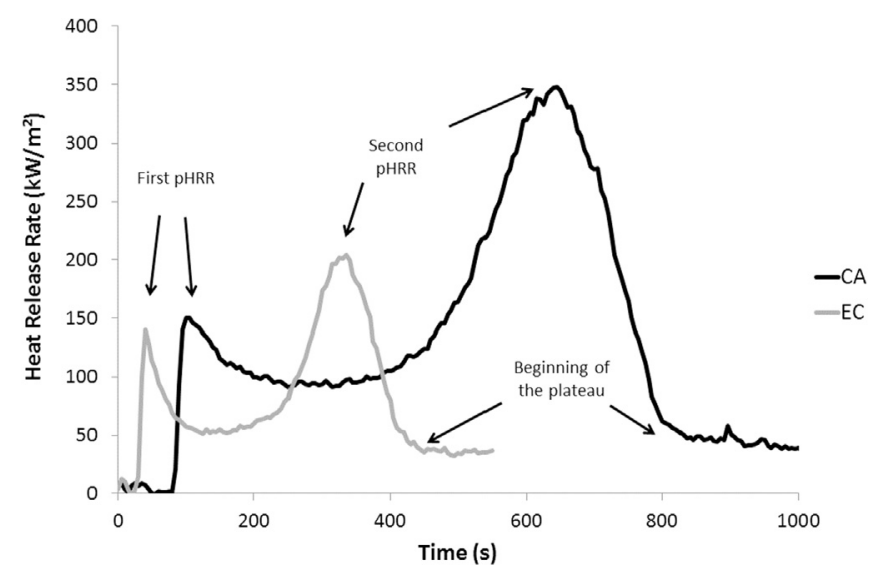

Fig. 6. HRR versus time for samples CA and EC in cone calorimeter tests.

considered as thermally thick.

Time-to-ignition increases when density increases as observed for epiradiator test (Fig. 7). This can be ascribed to lower thermal conductivity of less dense wood species [24]. Indeed, porosity limits the heat transfer from the surface to the sample bulk that allows a faster 
Table 5

Summary of results of cone calorimeter test.

\begin{tabular}{|c|c|c|c|c|c|c|c|c|}
\hline Code & $\begin{array}{l}\text { Density } \\
\left(\mathrm{kg} / \mathrm{m}^{3}\right)\end{array}$ & TTI (s) & $\begin{array}{l}\text { pHRR } 1 \\
\left(\mathrm{~kW} / \mathrm{m}^{2}\right)\end{array}$ & \multicolumn{2}{|c|}{ TpHRR1 $\left({ }^{\circ} \mathrm{C}\right)$} & \multicolumn{2}{|c|}{$\begin{array}{l}\text { pHRR2 } \\
\left(\mathrm{kW} / \mathrm{m}^{2}\right)\end{array}$} & TpHRR2 (s) \\
\hline TD & 448 & $38 / 36$ & $124 / 116$ & \multicolumn{2}{|l|}{45} & \multicolumn{2}{|l|}{248} & $330 / 325$ \\
\hline $\mathrm{EC}$ & 504 & $32 / 38$ & $140 / 128$ & \multicolumn{2}{|c|}{$40 / 45$} & \multicolumn{2}{|c|}{$204 / 252$} & $335 / 325$ \\
\hline TR & 604 & $56 / 57$ & $125 / 128$ & \multicolumn{2}{|c|}{70} & \multicolumn{2}{|c|}{240} & $395 / 365$ \\
\hline SH & 655 & $65 / 70$ & $128 / 129$ & \multicolumn{2}{|c|}{$70 / 80$} & \multicolumn{2}{|c|}{$246 / 215$} & $405 / 470$ \\
\hline LA & 685 & $75 / 68$ & $128 / 162$ & \multicolumn{2}{|c|}{$80 / 75$} & \multicolumn{2}{|c|}{$256 / 288$} & $450 / 390$ \\
\hline CA & 1130 & $87 / 98$ & $150 / 137$ & \multicolumn{2}{|c|}{$100 / 120$} & \multicolumn{2}{|c|}{$348 / 341$} & $645 / 595$ \\
\hline $\mathrm{TC}$ & 1234 & $133 / 155 \quad 2$ & $212 / 186$ & \multicolumn{2}{|c|}{$145 / 165$} & \multicolumn{2}{|c|}{$409 / 369$} & $630 / 625$ \\
\hline Code & $\begin{array}{l}\text { Density } \\
\left(\mathrm{kg} / \mathrm{m}^{3}\right)\end{array}$ & $\begin{array}{l}\text { THR before } \\
\text { plateau } \\
(\mathrm{kJ} / \mathrm{g})\end{array}$ & \multicolumn{2}{|c|}{$\begin{array}{l}\text { EHC before } \\
\text { plateau } \\
(\mathrm{kJ} / \mathrm{g})\end{array}$} & \multicolumn{2}{|c|}{$\begin{array}{l}\text { Residue } \\
\text { before } \\
\text { plateau (wt } \\
\% \text { ) }\end{array}$} & \multicolumn{2}{|c|}{$\begin{array}{l}\text { Minimum HRR } \\
\text { between pHRR } \\
\left(\mathrm{kW} / \mathrm{m}^{2}\right)\end{array}$} \\
\hline TD & 448 & $8.6 / 9.3$ & $10.6 /$ & 12.6 & $18.6 / 2$ & 6.4 & & \\
\hline $\mathrm{EC}$ & 504 & 7.9 & $11.1 /$ & 12.3 & $28.8 / 3$ & & & \\
\hline TR & 604 & $9.8 / 8.5$ & 12.1 & 10.5 & 19.3 & & & \\
\hline SH & 655 & $10.2 / 8.1$ & 11.7/ & 11.8 & $27 / 30$ & & & \\
\hline LA & 685 & $5.6 / 6.7$ & $8.2 / 1$ & 0.6 & $31.9 / 3$ & 6.5 & & \\
\hline CA & 1130 & 10.8 & 13.9/ & 14.0 & $22.3 / 2$ & & & 103 \\
\hline $\mathrm{TC}$ & 1234 & $10.3 / 8.5$ & $14.2 /$ & 11.7 & 27.2 & & & 105 \\
\hline
\end{tabular}

Table 6

Summary of smoke results of cone calorimeter test.

\begin{tabular}{lllll}
\hline Code & Density $\left(\mathrm{kg} / \mathrm{m}^{3}\right)$ & TSR $\left(\mathrm{m}^{2} / \mathrm{g}\right)$ & THR $(\mathrm{kJ} / \mathrm{g})$ & Ratio TSR/THR $\left(\mathrm{m}^{2} / \mathrm{kJ}\right)$ \\
\hline TD & 448 & $6.2-7.3 \mathrm{E}-02$ & $8.6 / 9.3$ & $7.2-7.9 \mathrm{E}-03$ \\
EC & 504 & $6.1-7.0 \mathrm{E}-02$ & 7.9 & $7.7-8.9 \mathrm{E}-03$ \\
TR & 604 & $6.1-7.6 \mathrm{E}-02$ & $9.8 / 8.5$ & $7.8-9.0 \mathrm{E}-03$ \\
SH & 655 & $4.7-5.3 \mathrm{E}-02$ & $10.2 / 8.1$ & $5.5-5.8 \mathrm{E}-03$ \\
LA & 685 & $3.3-3.7 \mathrm{E}-02$ & $5.6 / 6.7$ & $5.5-6.6 \mathrm{E}-03$ \\
CA & 1130 & $2.4-2.5 \mathrm{E}-01$ & 10.8 & $2.3 \mathrm{E}-02$ \\
TC & 1234 & $2.0-2.1 \mathrm{E}-01$ & $10.3 / 8.5$ & $2.0-2.4 \mathrm{E}-02$ \\
& & & & \\
\hline
\end{tabular}

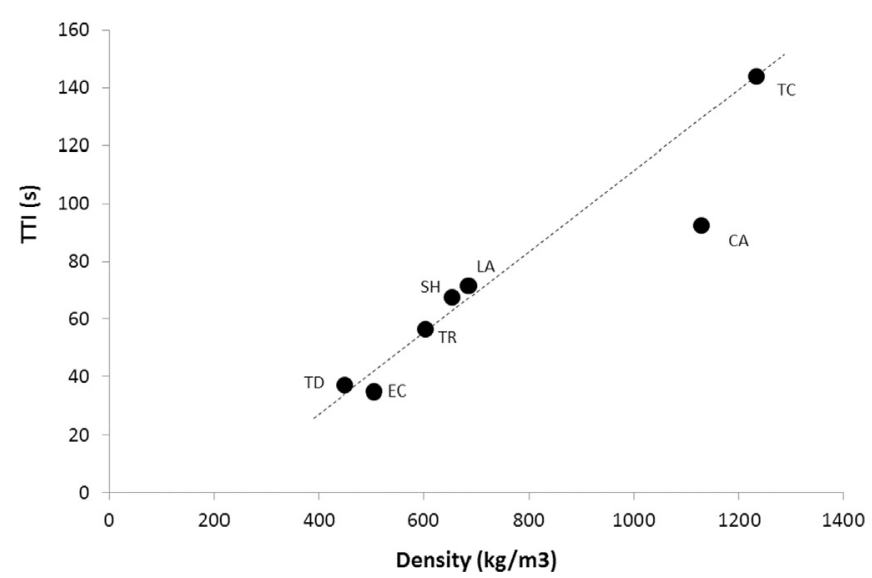

Fig. 7. Time-to-ignition versus density for all wood samples in cone calorimeter tests.

increase of the surface temperature. CA exhibits a quite unexpected low time-to-ignition as already suggested from epiradiator tests. Time-toignition in cone calorimeter and time-to-first ignition in epiradiator test are perfectly correlated (Fig. 8). Time-to-ignition depends on a couple of parameters including the spectral distribution of the radiation, i.e. heat source and the heat absorbance of the sample. The low time-toignition of CA needs further investigation.

For each sample, the first peak of HRR is significantly lower than the second one (Fig. 9). The first pHRR is in the range $120-145 \mathrm{~kW} / \mathrm{m}^{2}$ for all species except the densest one (TC $-199 \mathrm{~kW} / \mathrm{m}^{2}$ ).

Concerning the second pHRR, two groups can be separated. CA and TC as denser species exhibit much higher pHRR $\left(350-400 \mathrm{~kW} / \mathrm{m}^{2}\right)$ at

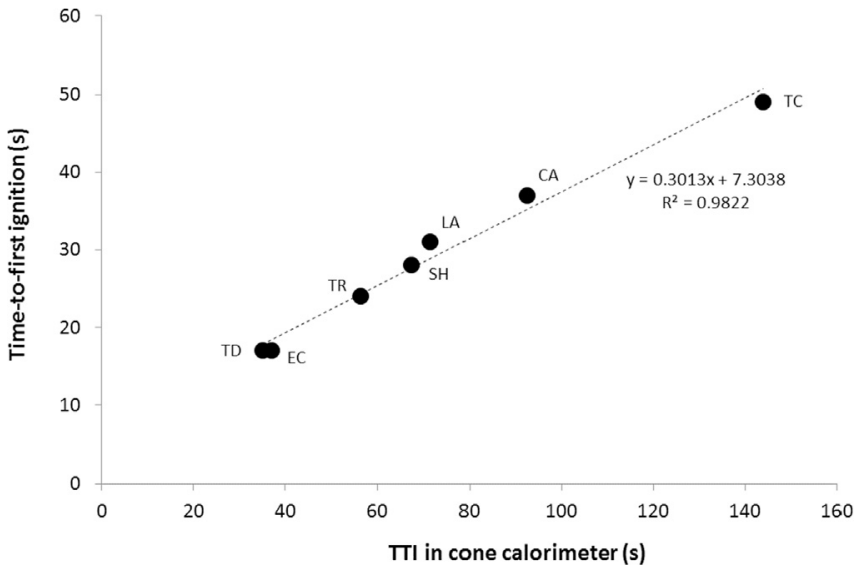

Fig. 8. Time-to-first ignition from epiradiator test versus time-to-ignition from cone calorimeter test for all wood samples.

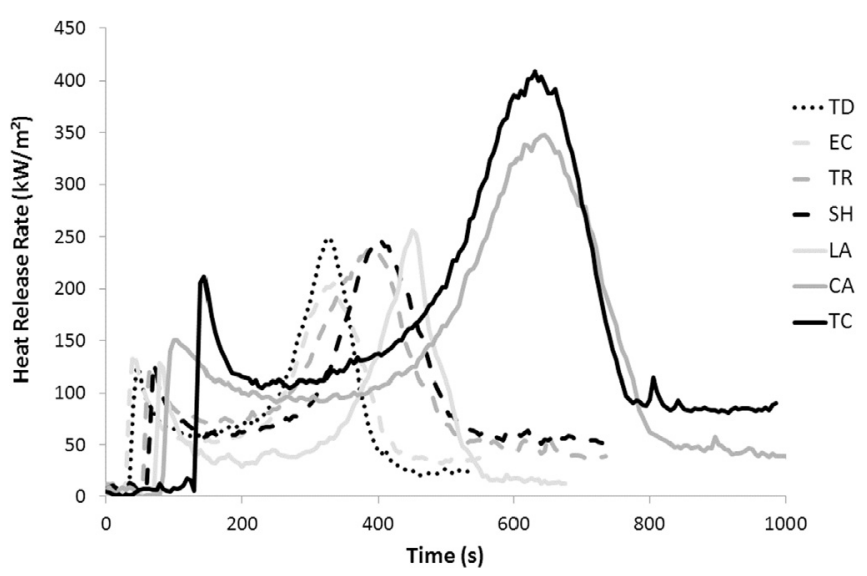

Fig. 9. HRRversus time of all the hardwood samples in cone calorimeter tests.

significantly longer times. All other wood species can be gathered in a second group with pHRR mainly in the range $220-270 \mathrm{~kW} / \mathrm{m}^{2}$ (Fig. 10).

Total heat release and effective heat of combustion were calculated for each sample at the beginning of plateau, i.e. before thermo-oxidation (pyrolysis is believed to be anaerobic before the flame vanishes). Total heat release at the beginning of plateau is in the range $6.2-10.8 \mathrm{~kJ} / \mathrm{g}$, i.e. slightly lower (-15\%) than the values measured in PCFC (in anaerobic conditions). This gap can be assigned to an incomplete combustion in cone calorimeter test. CA and LA exhibit respectively the highest and the lowest total heat release as already observed in PCFC.

Even if there are some differences in residue content, this tendency is also observed for effective heat of combustion (see Table 5). LA has the lowest effective heat of combustion at the beginning of plateau while CA has the highest value. This evidences that the pyrolytic gases (and the compositions) are different between these wood species.

Residues at the beginning of the plateau range from 22.5 to $34.2 \mathrm{wt}$ $\%$ but no clear tendency with density is observed (Table 5). Note that LA exhibits the highest residue content. During plateau, the residue content decreases continuously due to thermo-oxidation. This decrease is similar for all wood samples. Its mean value is around $2 \mathrm{wt} \%$ during the first 100 s of plateau.

Another interesting point concerns the minimum reached by the heat release rate between the two pHRR. Indeed, it may be suggested that flame out can occur if the HRR decreases after pHRR1 below a threshold value. For all the wood samples tested in this article, it is not the case, and HRR starts increasing up to a second and intense pHRR. It can be noted that this minimum value of HRR ranges from 34 to $99 \mathrm{~kW} /$ $\mathrm{m}^{2}$. No correlation with density is observed even if this value is 


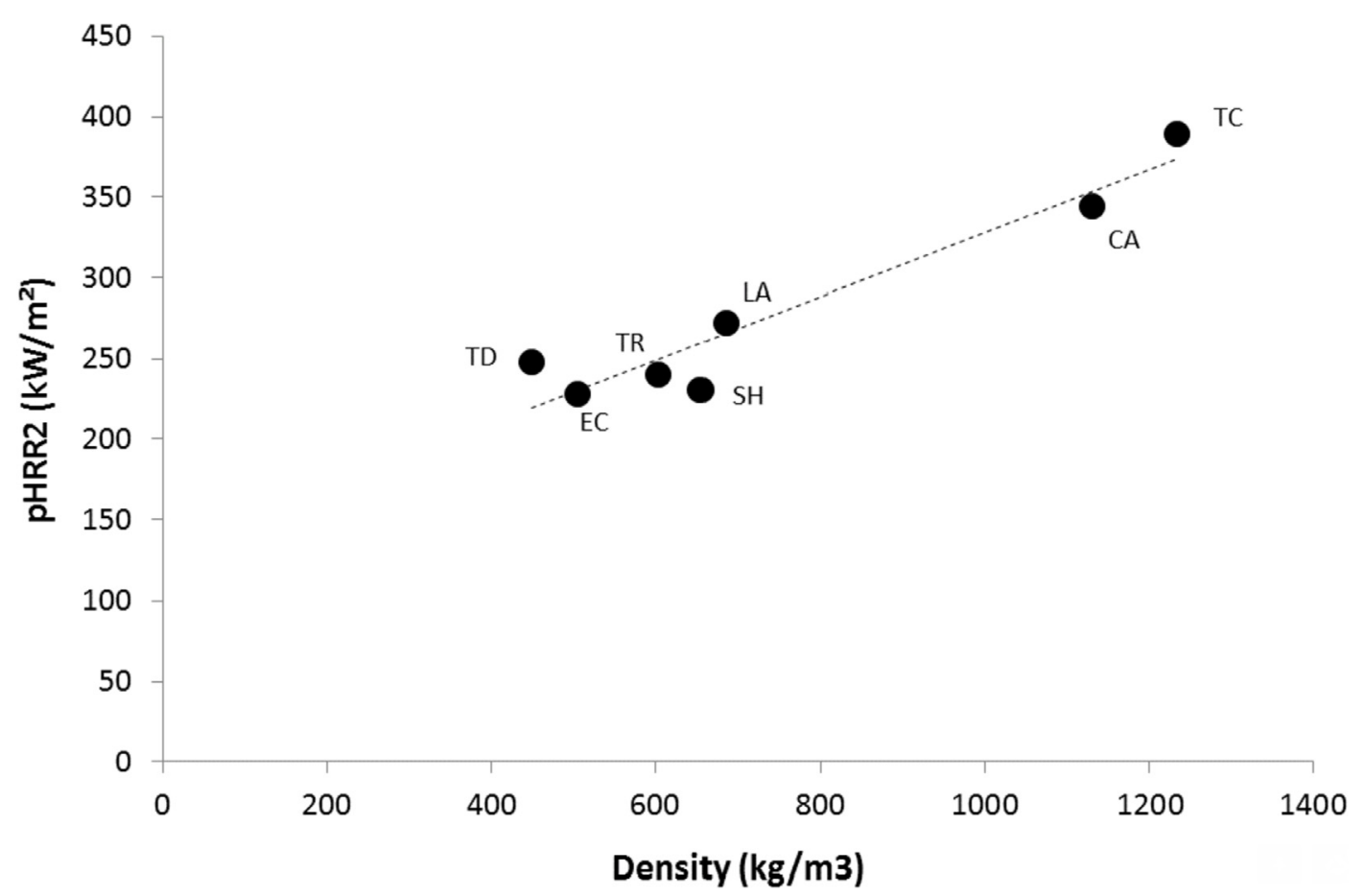

Fig. 10. Second peak of heat release rate versus density for all wood samples.

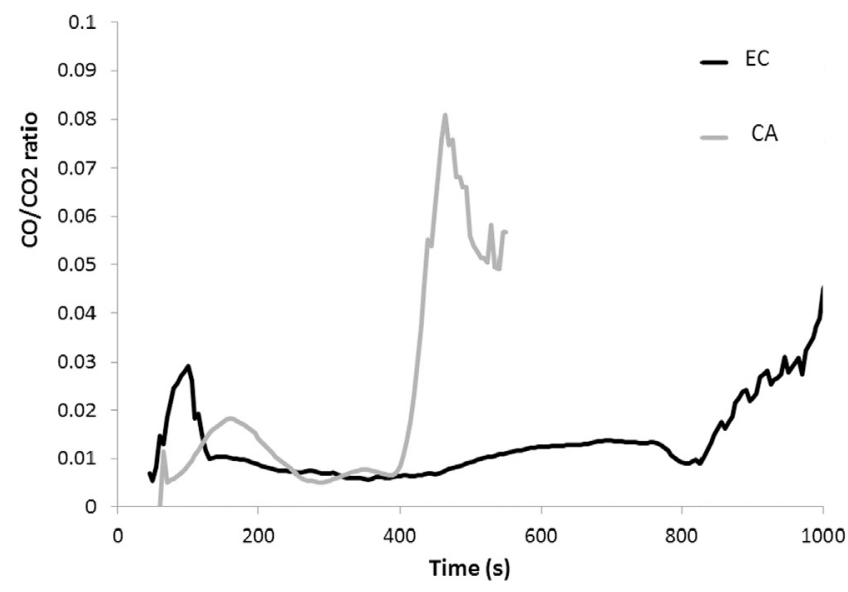

Fig. 11. $\mathrm{CO} / \mathrm{CO} 2$ ratio versus time for two wood samples in cone calorimeter tests.

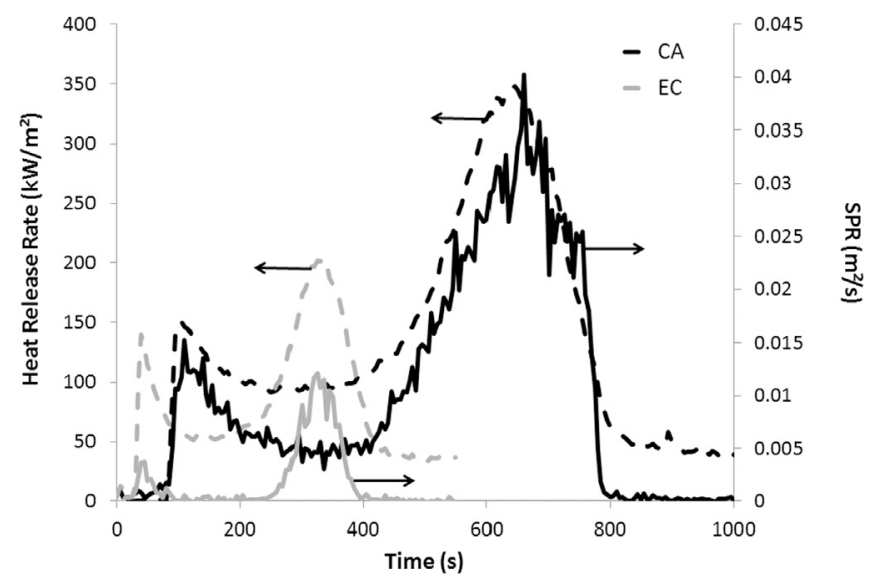

Fig. 12. Smoke production rate and HRR versus time for two wood samples in cone calorimeter tests. significantly higher for the two densest samples. Once again, LA exhibits the lowest value, i.e. LA may be the closest sample to flame out.

Smoke production and $\mathrm{CO} / \mathrm{CO}_{2}$ ratio are other important data to assess the fire hazard. $\mathrm{CO} / \mathrm{CO}_{2}$ ratio is shown in Fig. 11 for CA and EC wood species. Similar curves are observed for all other species. The ratio is initially low with a small peak corresponding to the first pHRR1. Nevertheless, it increases sharply when thermo-oxidation starts. Indeed when flame vanishes, temperature in the zone above sample decreases and oxidation of partially oxidized gases released from aerobic pyrolysis becomes incomplete or even is stopped. Smoke production rate (SPR) is shown in Fig. 12 for CA and EC together with HRR curves. SPR curves exhibit two peaks for each wood species corresponding to the two peaks of heat release rate. Obviously, the smoke release increases when heat release increases. Nevertheless, the ratio between the first and the second peaks of SPR is most often lower than the ratio between the first and the second peaks of HRR. It means that the smoke release per released energy unit is more important during thermo-oxidation, in good agreement with the observed increase of $\mathrm{CO} / \mathrm{CO}_{2}$ ratio. Interestingly significant differences between wood species can be found even during anaerobic pyrolysis. Table 6 shows the total smoke production, total heat release and ratio between them at the beginning of the plateau. CA and TC exhibit significant higher values of both total smoke production (in $\mathrm{m}^{2} / \mathrm{g}$ ) and smoke per released energy (in $\mathrm{m}^{2} / \mathrm{kJ}$ ) confirming that the densest wood species have specific fire properties in comparison to other ones. The lowest values are observed for LA, confirming this wood species induces a lower fire hazard.

\section{Conclusions}

The assessment of the fire reaction of seven tropical wood species has been carried out using different fire tests with a particular attention to the role of density. The experimental methods developed have allowed us to compare different aspects.

In general, rather good relation is found between time-to-ignition and density, which can be easily explained by the lower thermal conductivity of more porous materials. This correlation is observed in the evolution of the time-to-ignition in the epiradiator and the cone calorimeter tests. Tabebuia donnell-smithii (TD) and Enterolobium 
cyclocarpum (EC) exhibit the lowest values, followed by Tabebuia rosea (TR), Swietenia humilis (SH) and Lysiloma acapulcensis (LA). Finally, wood samples with high density, Cordia elaeagnoides (CA) and Tabebuia chrysantha (TC), show the longest time-to-ignition. This trend is also found in the peak temperatures of the cone calorimeter test. Peaks of heat release rate appear at lower temperatures for the species with lower densities. However, there is no correlation with wood density in the magnitude of the heat release rate peaks of the cone calorimeter test, the flame persistence in the epiradiator test or the LOI values. Therefore, other factors related to composition (inorganic compounds) or wood morphology must be taken into account because of its significant influence in the fire behaviour. That is the case of Lysiloma acapulcensis (LA) species, which exhibits higher LOI and residue content, and lower THR and smoke release among all wood species despite its medium density.

More dense wood species like Cordia eleagnoides (CA) and Tabebuia chrysantha (TC) exhibit specific properties as slightly higher pHRR or higher smoke release. This is due to the greater mass of the more dense wood samples.

\section{Acknowledgments}

This research has been carried out within the framework of the COST Action FP 1404.

The authors express their gratitude to the Michoacana University of San Nicolás de Hidalgo Research Programme 2015-2016 for supplying the samples of tropical wood for this research.This work is supported by MINECO (Spain) under the project BIA2014-52688-R. The authors would also like to thank the Catalan Government for the quality accreditation given to the research group GICITED (2014 SGR 1298).

\section{References}

[1] E. Hugi, R. Weber, Fire behaviour of tropical and European wood and fire resistance of fire doors made of this wood, Fire Technol. 48 (2012) 679-698.

[2] J.M. Njankouo, J.C. Dotreppe, J.M. Franssen, Experimental study of the charring rate of tropical hardwoods, Fire Mater. 28 (2004) 15-24.

[3] A. Bartlett, R.M. Hadden, L.A. Bisby, A. Law, Analysis of cross-laminated timber charring rates upon exposure to nonstandard heating conditions, Fire Mater. 201514th Int. Conf. Exhib. Proc., Interscience Communications Ltd, 2015, pp. 667-681.

[4] K.L. Friquin, Material properties and external factors influencing the charring rate of solid wood and glue-laminated timber, Fire Mater. 35 (2011) 303-327, https:// doi.org/10.1002/fam.1055.
[5] B.B. Hallac, A.J. Ragauskas, Analyzing cellulose degree of polymerization and its relevancy to cellulosic ethanol, Biofuels, Bioprod. Biorefining 5 (2011) 215-225, https://doi.org/10.1002/bbb.269.

[6] J.C.F. Walker, Primary Wood Processing: Principles and Practice, second ed., Springer, Netherlands, 2006, https://doi.org/10.1007/1-4020-4393-7.

[7] H. Yang, R. Yan, H. Chen, D.H. Lee, C. Zheng, Characteristics of hemicellulose, cellulose and lignin pyrolysis, Fuel 86 (2007) 1781-1788, https://doi.org/10.1016/ j.fuel.2006.12.013.

[8] L. Lowden, T. Hull, Flammability behaviour of wood and a review of the methods for its reduction, Fire Sci. Rev. 2 (2013) 4, https://doi.org/10.1186/2193-0414-2-4.

[9] R.H. White, M.A. Dietenberger, Wood Products;: thermal degradation and fire, Encycl. Mater. Sci. Technol. 48 (2001) 9712-9716.

[10] R.G. Stanley, Extractives of wood, bark, and needles of the southern pines, For. Prod. J. 19 (1969) 50-56.

[11] R.H. White, Effect of lignin content and extractives on the higher heating value of wood, Wood Fiber Sci. 19 (1987) 446-452.

[12] M. Müller-Hagedorn, H. Bockhorn, L. Krebs, U. Müller, A comparative kinetic study on the pyrolysis of three different wood species, J. Anal. Appl. Pyrolysis 68-69 (2003) 231-249, https://doi.org/10.1016/S0165-2370(03)00065-2.

[13] H. Yang, R. Yan, H. Chen, C. Zheng, D.H. Lee, D.T. Liang, Influence of minera matter on pyrolysis of palm oil wastes, Combust. Flame 146 (2006) 605-611, https://doi.org/10.1016/j.combustflame.2006.07.006.

[14] J. Zule, J. Dolenc, Distribution of mineral substances in different wood tissues of European larch (larix decidua mill.), Drv. Ind. 63 (1) (2012) 19-25.

[15] L.E.A. Ávila-Calderón, J.G. Rutiaga-Quiñones, Wood chemical components of three species from a medium deciduous forest, Wood Res. 60 (3) (2015) 463-470.

[16] N. Torelli, K. Cufar, Mexican tropical hardwoods. Comparative study of ash and silica content, Holz als Roh- Werkst. 53 (1) (1995) 61-62.

[17] R.H. White, Oxygen Index evaluation of fire-retardant-treated wood, Wood Sci. 12 (1978) 113-122.

[18] T. Hosoya, H. Kawamoto, S. Saka, Cellulose-hemicellulose and cellulose-lignin interactions in wood pyrolysis at gasification temperature, J. Anal. Appl. Pyrolysis 80 (2007) 118-125, https://doi.org/10.1016/j.jaap.2007.01.006.

[19] K. Raveendran, A. Ganesh, K.C. Khilar, Influence of mineral matter on biomass pyrolysis characteristics, Fuel 74 (1995) 1812-1822, https://doi.org/10.1016/ 0016-2361(95)80013-8.

[20] T. Hosoya, H. Kawamoto, S. Saka, Pyrolysis behaviors of wood and its constituent polymers at gasification temperature, J. Anal. Appl. Pyrolysis 78 (2007) 328-336, https://doi.org/10.1016/j.jaap.2006.08.008.

[21] S. Liodakis, D. Bakirtzis, A. Dimitrakopoulos, Ignition characteristics of forest species in relation to thermal analysis data, Thermochim. Acta 390 (2002) 83-91, https://doi.org/10.1016/S0040-6031(02)00077-1.

[22] G. Dorez, L. Ferry, R. Sonnier, A. Taguet, J.-M. Lopez-Cuesta, Effect of cellulose, hemicellulose and lignin contents on pyrolysis and combustion of natural fibers, $\mathrm{J}$ Anal. Appl. Pyrolysis 107 (2014) 323-331, https://doi.org/10.1016/j.jaap.2014. 03.017.

[23] B. Schartel, T.R. Hull, Development of fire-retarded materials-interpretation of cone calorimeter data, Fire Mater. 31 (2007) 327-354, https://doi.org/10.1002/ fam.949.

[24] D. Hopkins, J.G. Quintiere, Material fire properties and predictions for thermoplastics, Fire Saf. J. 26 (1996) 241-268, https://doi.org/10.1016/S0379-7112(96) 00033-1. 